\title{
Kadar D-Dimer Plasma sebagai Prediktor Kematian Penderita Pneumonia Usia 2-59 Bulan
}

\author{
Retno Saraswati, ${ }^{1}$ Dzulfikar D. Lukmanul Hakim, ${ }^{2}$ Herry Garna ${ }^{2}$ \\ ${ }^{1}$ Rumah Sakit MH. Thamrin Cileungsi, ${ }^{2}$ Departemen Ilmu Kesehatan Anak Fakultas Kedokteran \\ Universitas Padjadjaran-Rumah Sakit Hasan Sadikin Bandung
}

\begin{abstract}
Abstrak
Pada pneumonia berat, terjadi koagulasi intravaskular dan intraalveolar yang merupakan respons proses inflamasi lokal dan sistemik infeksi paru. Konsekuensi klinis dari perubahan koagulasi ini yaitu peningkatan kadar D-dimer plasma sebagai petanda aktivitas koagulasi dan fibrinolisis serta meluasnya disfungsi organ bahkan kematian. Tujuan penelitian ini untuk mengetahui validitas kadar D-dimer plasma yang tinggi sebagai prediktor kematian penderita pneumonia usia 2 sampai 59 bulan. Penelitian ini merupakan penelitian observasional analitik dengan rancangan prospektif yang dilaksanakan di Rumah Sakit Dr. Hasan Sadikin Bandung. Subjek penelitian anak usia 2 sampai 59 bulan yang didiagnosis sebagai pneumonia dan berobat ke Instalasi Gawat Darurat Anak selama bulan Oktober-November 2009. Pemeriksaan D-dimer plasma dilakukan saat penderita datang dan kemudian dilakukan observasi sampai penderita meninggal atau dipulangkan dari rumah sakit. Empat puluh lima anak ikut serta dalam penelitian ini, 15 (33\%) di antaranya meninggal selama observasi. Kadar D-dimer plasma menunjukkan hubungan yang bermakna $(\mathrm{p}=0,04)$ terhadap kematian penderita pneumonia dengan median dan rentang sebesar $0,60 \mathrm{mg} / \mathrm{L}$ $(0,1-5,10 \mathrm{mg} / \mathrm{L})$. Cut-off point D-dimer plasma $>0,4 \mathrm{mg} / \mathrm{L}$ sebagai prediktor kematian penderita pneumonia memberikan sensitivitas 73,3\% (IK 95\%; 44,9-92,0) dan spesifisitas 70,0\% (IK 95\%; 50,6-85,2\%) dengan akurasi $71,1 \%$. Simpulan, kadar D-dimer plasma yang tinggi dapat memprediksi kematian penderita pneumonia usia 2 sampai 59 bulan. [MKB. 2012;44(1):57-62].
\end{abstract}

Kata kunci: Kadar D-dimer plasma, koagulasi, pneumonia, prediktor kematian

\section{Plasma D-Dimer Level as Predictor of Mortality in 2-59-Month-Old Pneumonia Patients}

\begin{abstract}
Intravascular and intraalveolar coagulation can be found in severe pneumonia as a response to local and systemic inflammation process in severe pneumonia. Clinical consequences of this coagulation changes is an increase of plasma D-dimer levels as a marker of coagulation and fibrinolyis activation, the number of organ dysfunction even death. The aim of this study was to understand the validity of high plasma D-dimer levels as a predictor of mortality in 2 to 59-month-old pneumonia patients. This was a prospective observational analytic study which was held in Dr. Hasan Sadikin Hospital Bandung. The subjects of this study were 2 to 59 months old children who were diagnosed as pneumonia and visited Pediatric Emergency Departement during October-November 2009. Plasma D-dimer assay was performed at admission and observed until the patient died or discharged from the hospital. Forty-five children were included in this study, 15 (33\%) died during observation. Plasma D-dimer level showed significant correlations $(\mathrm{p}=0.04)$ with the mortality in 2 to 59 -month-old pneumonia patients with median and range of $0.60 \mathrm{mg} / \mathrm{L}(0.1-5.10 \mathrm{mg} / \mathrm{L})$. Plasma D-dimer cut-off point of $>0.4 \mathrm{mg} / \mathrm{L}$ gave $73.3 \%$ sensitivity (CI $95 \%$, $44.9-92.0 \%$ ), and $70.0 \%$ specificity (CI 95\%, 50.6-85.2\%) with 71.1\% accuracy for predicting mortality in 2 to 59-month-old pneumonia patients. In conclusions, there were significant correlations between elevated plasma Ddimer levels and mortality in 2 to 59-month-old patients with pneumonia. [MKB. 2012;44(1):57-62].
\end{abstract}

Key words: Coagulation, plasma D-dimer levels, pneumonia, predictor of mortality

Korespondensi: Retno Saraswati, dr., Sp.A, Rumah Sakit MH. Thamrin Cileungsi, jalan Narogong Km 16 Limusnunggal Cileungsi Bogor 16820, telepon (021) 8235052, mobile 08122353061,e-mail retno_1978@yahoo.co.id 


\section{Pendahuluan}

Penyebab kesakitan dan kematian tersering pada anak usia kurang 5 tahun di seluruh dunia yaitu pneumonia, dengan perkiraan 150 juta kasus baru setiap tahunnya di negara berkembang dan 20 juta di antaranya memerlukan perawatan di rumah sakit. ${ }^{1}$ Berdasarkan Riset Kesehatan Dasar 2007, prevalensi pneumonia nasional sebesar $2,13 \%$. Empat belas provinsi di Indonesia memiliki prevalensi pneumonia di atas prevalensi nasional dan salah satunya Jawa Barat $(2,43 \%){ }^{2}$

Sistem skoring pediatric risk of mortality (PRISM) dapat digunakan untuk menilai risiko mortalitas pada anak dengan sakit berat yang dirawat di Pediatric Intensive Care Unit (PICU) dengan menilai berat penyakit berdasarkan ketidaknormalan yang ditemukan dalam pemeriksaan fisis dan laboratorium. Sistem skoring ini memiliki beberapa keterbatasan seperti perlunya software khusus yang cukup mahal dan pelatihan khusus, serta panduan yang ketat untuk mencegah variasi interobserver yang lebar. ${ }^{3,4}$ Oleh karena itu, diperlukan cara lain yang lebih mudah, murah, dan cepat untuk menilai risiko mortalitas pada anak sakit berat.

Pada kasus pneumonia berat, terjadi koagulasi intravaskular dan intraalveolar yang merupakan respons proses inflamasi lokal dan sistemik infeksi paru. ${ }^{5,6}$ Lipopolisakarida bakteri, endotoksin dan sitokin proinflamasi seperti interleukin (IL)-1, IL6 , IL-10, serta tumor necrosis factor- $\alpha$ (TNF- $\alpha$ ) meningkatkan deposisi fibrin melalui tiga jalur utama, yaitu generasi trombin yang dimediasi oleh tissue factor (TF) oleh sel endotel dan monosit yang teraktivasi, disfungsi fisiologis mekanisme antikogulan, serta gangguan fibrinolisis karena depresi sistem fibrinolitik oleh PAI-1 ${ }^{7,8}$ Konsekuensi klinis perubahan koagulasi ini yaitu peningkatan kadar D-dimer plasma sebagai petanda aktivitas koagulasi dan fibrinolisis serta meluasnya disfungsi organ bahkan kematian. ${ }^{9,10}$ Penelitian terdahulu oleh Querol-Ribelles dkk. ${ }^{6}$ dan Milbrandt dkk. ${ }^{11}$ pada penderita pneumonia dewasa menunjukkan bahwa kadar D-dimer plasma sangat berhubungan dengan beratnya pneumonia dan kematian.

Penelitian ini bertujuan untuk mengetahui validitas kadar $\mathrm{D}$-dimer plasma yang tinggi sebagai prediktor kematian penderita pneumonia serta menentukan cut-off point kadar D-dimer plasma untuk memprediksi kematian penderita pneumonia usia 2-59 bulan.

\section{Metode}

Penelitian ini merupakan penelitian observasional analitik rancangan prospektif yang dilaksanakan di Instalasi Gawat Darurat RSHS Bandung pada bulan
Oktober sampai November 2009. Kriteria inklusi yaitu semua anak usia 2 sampai 59 bulan yang didiagnosis pneumonia serta mendapat persetujuan tertulis dari orangtua untuk ikut dalam penelitian setelah diberikan penjelasan (informed consent).

Penderita akan dieksklusi bila pada anamnesis dan pemeriksaan fisis ditemukan: 1) kelainan darah atau keganasan: hemofilia, leukemia, tumor solid, 2) menderita penyakit hati kronik seperti sirosis hati, 3) riwayat trauma atau baru menjalani operasi. Selama observasi, penderita dikeluarkan (drop out) dari penelitian apabila penderita dibawa pulang di luar persetujuan dokter (pulang paksa). Faktor perancu penelitian ini yaitu faktor risiko yang berhubungan dengan kematian penderita pneumonia yaitu berat badan lahir $<2.500$ gram, tidak mendapat ASI eksklusif selama 6 bulan, imunisasi yang tidak lengkap, paparan terhadap asap rokok dan asap dapur, defisiensi sistem imun serta penyakit penyerta seperti kelainan jantung, diare, asma, dan penyakit neuromuskular. ${ }^{12-15}$

Diagnosis klinis pneumonia ditegakkan berdasarkan pedoman tatalaksana pneumonia untuk sarana pelayanan kesehatan terbatas yang diterbitkan oleh World Health Organization (WHO) dan Departemen Kesehatan Republik Indonesia untuk rumah sakit rujukan tingkat pertama di kabupaten dan kota di Indonesia. ${ }^{16}$ Pembacaan foto toraks dilakukan oleh dua orang konsultan radiologi. Kesesuaian hasil pemeriksaan radiologis kedua radiolog diuji dengan coefficient agreement Kappa dan nilai 0,63 berarti ada kecocokan yang baik (menurut Fleiss) atau substansial (menurut Landis dan Koch).

Pengambilan darah vena dilakukan pada setiap subjek penelitian sebanyak $1,8 \mathrm{mLdan}$ dimasukkan ke dalam tabung sitrat untuk pemeriksaan kadar D-dimer plasma (NycoCard ${ }^{\mathbb{B}}$ D-dimer Single Test; Axis-shield, Norwegia). Selama perawatan, semua penderita mendapat perlakuan yang sama sesuai dengan standar pelayanan medis di Departemen Ilmu Kesehatan Anak RS Dr. Hasan Sadikin Bandung. Subjek penelitian diobservasi sampai penderita dipulangkan atau meninggal. Penderita yang pulang di luar persetujuan dokter akan dikeluarkan (drop out) dari penelitian.

Uji chi-kuadrat Pearson atau uji eksak Fisher digunakan untuk membandingkan karakteristik subjek penelitian dengan derajat keparahan dan kematian penderita pneumonia. Uji $t$ atau uji Mann-Whitney digunakan untuk menganalisis hubungan kadar D-dimer plasma dengan derajat keparahan dan kematian penderita pneumonia. Cut-off point kadar D-Dimer plasma sebagai prediktor kematian penderita pneumonia usia 2 sampai 59 bulan digunakan dengan kurva receiver operating characteristics (ROC), yang 
diikuti penghitungan sensitivitas, spesifisitas, dan akurasi. Kemaknaan hasil uji ditentukan berdasarkan nilai $\mathrm{p}<0,05$.

Semua penghitungan statistik dikerjakan dengan piranti lunak SPSS version 15.0 for windows tahun 2007, SPSS inc, Chicago-Illinois, USA.

\section{Hasil}

Subjek yang menyelesaikan penelitian ini sebanyak 45 (94\%) subjek dari 48 penderita yang memenuhi kriteria inklusi. Tiga subjek (6\%) tidak dapat melanjutkan penelitian karena penderita pulang tanpa persetujuan dokter yang merawat (pulang paksa).

Karakteristik subjek penelitian berdasarkan derajat keparahan pneumonia ternyata homogen (Tabel 1).

Berdasarkan hasil uji statistik pada faktor yang berhubungan dengan kematian penderita pneumonia, tidak terdapat perbedaan yang bermakna antara kelompok hidup dan meninggal (Tabel 2).

Analisis statistik dengan uji Mann-Whitney terhadap kadar D-dimer plasma antara kelompok penderita pneumonia yang hidup dan meninggal menunjukkan perbedaan bermakna antara kedua kelompok $(\mathrm{p}=0,04)$ dengan median dan rentang sebesar $0,20 \mathrm{mg} / \mathrm{L}(0,1-2,40 \mathrm{mg} / \mathrm{L})$ dan 0,60 $\mathrm{mg} / \mathrm{L}(0,1-5,10 \mathrm{mg} / \mathrm{L})$.

Sebaran cut-off point kadar D-dimer plasma pada kematian pneumonia sebagai berikut: Nilai cut-off point kadar D-dimer plasma $>0,4 \mathrm{mg} / \mathrm{L}$ memberikan sensitivitas 73,3\% (IK 95\%; 44,992,0) dan spesifisitas 70,0\% (IK 95\%; 50,6$85,2 \%$ ) dengan akurasi $71,1 \%$. Nilai prediksi kadar D-dimer plasma terhadap kematian menunjukkan area under the ROC curve (AUC) sebesar 0,684 (IK 95\%; 0,529-0,815) dengan $\mathrm{p}=0,036$. Angka-angka tersebut menunjukkan validitas kadar D-dimer plasma yang tinggi sebagai prediktor kematian penderita pneumonia usia 2 sampai 59 bulan (Tabel 3).

Kurva ROC untuk kadar D-dimer plasma sebagai prediktor kematian penderita pneumonia menunjukkan bahwa cut-off point kadar D-dimer plasma $>0,4 \mathrm{mg} / \mathrm{L}$ memberikan sensitivitas dan spesifisitas terbesar (Gambar 1).

\section{Pembahasan}

Faktor yang berhubungan dengan kematian penderita pneumonia ternyata tidak berbeda antara kelompok hidup dan kelompok meninggal. Hal ini menunjukkan homogenitas faktor risiko pneumonia pada kedua kelompok.

Kadar D-dimer plasma yang tinggi pada penelitian ini juga berhubungan dengan kematian penderita pneumonia $(\mathrm{p}<0,04)$. Kadar D-dimer plasma pada penderita yang meninggal lebih tinggi dibandingkan dengan penderita yang hidup yaitu $0,6(0,1-5,10) \mathrm{mg} / \mathrm{L}$ terhadap $0,20(0,1-$ $2,40) \mathrm{mg} / \mathrm{L}$. Penelitian oleh Querol-Ribelles dkk. ${ }^{6}$

Tabel 1 Karakteristik Subjek Penelitian berdasarkan Derajat Keparahan Pneumonia

\begin{tabular}{|c|c|c|c|}
\hline \multirow[b]{2}{*}{ Karakteristik } & \multicolumn{2}{|c|}{ Derajat Keparahan Pneumonia } & \multirow[b]{2}{*}{$\mathbf{p}$} \\
\hline & $\begin{array}{c}\begin{array}{c}\text { Pneumonia Berat } \\
(\mathrm{n}=28)\end{array} \\
\end{array}$ & $\begin{array}{c}\text { Pneumonia Sangat Berat } \\
(\mathrm{n}=17)\end{array}$ & \\
\hline \multicolumn{4}{|l|}{ Jenis kelamin ${ }^{*}$} \\
\hline Laki-laki & 16 & 10 & 0,912 \\
\hline Perempuan & 12 & 7 & \\
\hline \multicolumn{4}{|l|}{ Usia (bulan)* } \\
\hline$<12$ & 15 & 14 & 0,178 \\
\hline $12-23$ & 8 & 3 & \\
\hline $24-35$ & 3 & 0 & \\
\hline$>35$ & 2 & 0 & \\
\hline \multicolumn{4}{|l|}{ Status gizi* } \\
\hline Baik & 23 & 9 & 0,105 \\
\hline Malnutrisi sedang & 3 & 4 & \\
\hline Malnutrisi berat & 2 & 4 & \\
\hline \multicolumn{4}{|l|}{ Pendidikan ibu* } \\
\hline Tidak diketahui & 0 & 1 & 0,449 \\
\hline SD & 5 & 3 & \\
\hline SMP & 12 & 6 & \\
\hline SMA & 8 & 7 & \\
\hline Akademi/S-1 & 3 & 0 & \\
\hline
\end{tabular}

Keterangan: "nilai yang disajikan merupakan jumlah dan persentase subjek, ${ }^{\circledR}$ uji statistik dengan uji chi-kuadrat Pearson 
Tabel 2 Faktor Risiko dan Kematian Penderita Pneumonia

\begin{tabular}{|c|c|c|c|}
\hline \multirow[b]{2}{*}{ Faktor Risiko* } & \multicolumn{2}{|c|}{ Pneumonia } & \multirow[b]{2}{*}{$\mathbf{p}$} \\
\hline & $\begin{array}{l}\text { Hidup } \\
(\mathrm{n}=30)\end{array}$ & $\begin{array}{c}\text { Meninggal } \\
(\mathrm{n}=15)\end{array}$ & \\
\hline Berat badan lahir $<2.500$ gram & 3 & 3 & $0,384^{4}$ \\
\hline Tidak mendapat ASI eksklusif & 18 & 8 & $0,754^{4}$ \\
\hline Imunisasi tidak lengkap & 18 & 8 & $0,670^{\S}$ \\
\hline Terpapar asap rokok & 26 & 15 & $0,285^{4}$ \\
\hline Polusi rumah tangga & 14 & 7 & $1,000^{\S}$ \\
\hline Kelainan jantung & 7 & 5 & $0,496^{\pi}$ \\
\hline Diare & 6 & 7 & $0,086^{\circ}$ \\
\hline Asma & 1 & 0 & $1,000^{\natural}$ \\
\hline Defisiensi sistem imun & 1 & 2 & $0,254^{4}$ \\
\hline
\end{tabular}

Keterangan: "nilai yang disajikan merupakan jumlah dan persentase subjek, "uji statistik dengan uji eksak Fisher, ${ }^{\S}$ uji statistik dengan uji chi-kuadrat Pearson

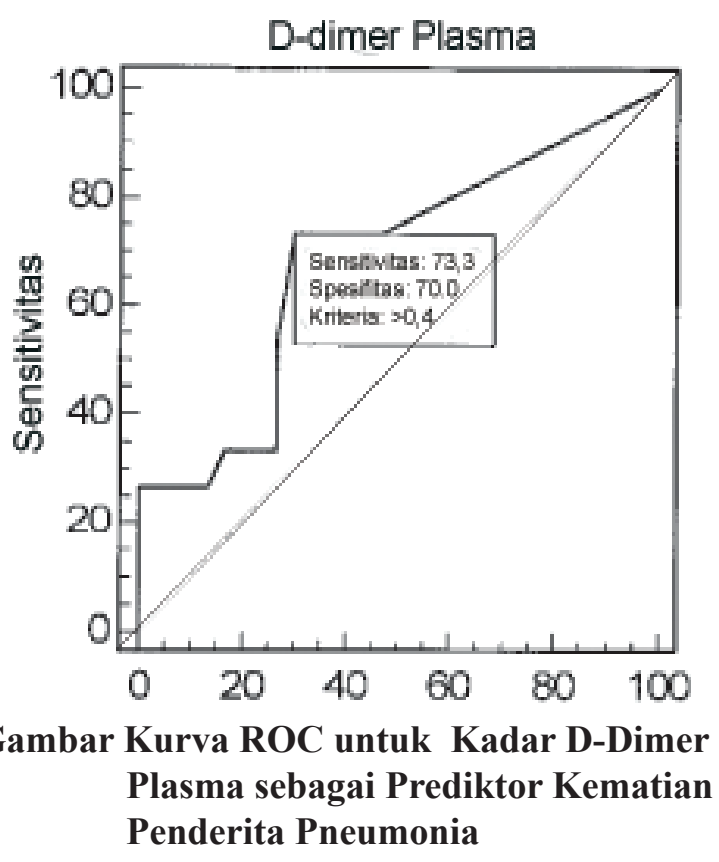

dan Shorr dkk. ${ }^{9}$ mendapatkan hubungan kadar D-dimer plasma dengan kematian penderita sakit kritis dan pneumonia. Sementara penelitian Shilon dkk. ${ }^{17}$ walaupun terdapat hubungan antara kadar D-dimer plasma dan beratnya penyakit, ternyata secara statistik tidak terdapat hubungan kadar D-dimer plasma dengan timbulnya disfungsi organ serta kematian penderita pneumonia.

Cut-off point kadar D-dimer plasma $>0,4 \mathrm{mg} / \mathrm{L}$ memberikan sensitivitas $73,33 \%$ dan spesifisitas 70,0\%; sedangkan cut-off point kadar D-dimer plasma $>0,5 \mathrm{mg} / \mathrm{L}$ mempunyai sensitivitas $53,33 \%$ dan spesifisitas $73,33 \%$. Cut-off point kadar D-dimer plasma $>0,4 \mathrm{mg} / \mathrm{L}$ memberikan sensitivitas yang lebih tinggi bila dibandingkan dengan kadar D-dimer plasma $>0,5 \mathrm{mg} / \mathrm{L}$ yang berarti lebih banyak penderita pneumonia yang diprediksi dapat meninggal. Penggunaan kadar D-dimer plasma $>0,5 \mathrm{mg} / \mathrm{L}$ memberikan sensitivitas yang lebih rendah karena sebagian penderita pneumonia yang meninggal luput dari prediksi karena belum mencapai kadar D-dimer plasma $>0,5 \mathrm{mg} / \mathrm{L}$. Nilai spesifisitas kadar D-dimer plasma $>0,4 \mathrm{mg} / \mathrm{L}$ lebih rendah karena tidak semua penderita dengan kadar tersebut akan meninggal, sedangkan kadar D-dimer plasma $>0,5 \mathrm{mg} / \mathrm{L}$ mempunyai spesifisitas yang lebih tinggi karena kemungkinan penderita pneumonia meninggal akan lebih besar. Karena kemampuan untuk memprediksi kematian lebih tinggi dan perlunya penentuan kadar D-dimer plasma untuk meningkatkan kewaspadaan serta pemberian tindakan yang cepat dan tepat, maka peneliti menggunakan kadar D-dimer plasma $>0,4 \mathrm{mg} / \mathrm{L}$ sebagai cut-off point.

Perbedaan satuan pada penelitian ini dengan penelitian terdahulu disebabkan oleh metode pemeriksaan yang berbeda. Penelitian terdahulu banyak menggunakan metode enzyme linked immunoassay (ELISA), sedangkan penelitian ini menggunakan metode imunofiltrasi (NycoCard ${ }^{\mathbb{B}}$ D-dimer Single Test; Axis-shield, Norwegia). Metode ini memiliki beberapa keunggulan dibandingkan dengan ELISA, di antaranya memiliki waktu pemeriksaan lebih cepat $(<5$ menit) dengan sensitivitas, spesifisitas, serta nilai prediksi negatif dan positif yang sebanding dengan baku emas ELISA. ${ }^{18}$

Cara lain menginterpretasikan peningkatan D-dimer plasma yaitu dengan menyatakan kadar D-dimer plasma meningkat bila kadarnya lebih dari batas atas nilai normal dan sangat meningkat bila kadarnya mencapai lima kali lipat batas atas nilai normal. ${ }^{19}$

Keterbatasan pada penelitian ini, pertama yaitu faktor risiko pneumonia berdasarkan penelitian terdahulu ternyata sebagian besar tidak menunjukkan hubungan dengan derajat keparahan maupun keluaran pneumonia, hal ini kemungkinan disebabkan oleh karena latar 
Tabel 3 Sensitivitas dan Spesifisitas Cut-off Point Kadar D-Dimer Plasma terhadap Kematian Penderita Pneumonia

\begin{tabular}{ccccc}
\hline $\begin{array}{c}\text { Kadar } \\
\text { D-Dimer Plasma }\end{array}$ & Sensitivitas & IK 95\% & Spesifisitas & IK 95\% \\
\hline$>0,1$ & 100,00 & $78,0-100,0$ & 0 & $0-11,7$ \\
$>\mathbf{0 , 4}$ & $\mathbf{7 3 , 3 3}$ & $44,9-92,0$ & $\mathbf{7 0 , 0 0}$ & $50,6-85,2$ \\
$>0,5$ & 53,33 & $26,6-78,7$ & 73,33 & $54,1-87,7$ \\
$>0,8$ & 33,33 & $11,9-61,6$ & 76,67 & $57,7-90,0$ \\
$>1$ & 26,67 & $8,0-55,1$ & 86,67 & $69,3-96,2$ \\
$>1,6$ & 26,67 & $8,0-55,1$ & 96,67 & $82,7-99,4$ \\
$>2,4$ & 26,67 & $8,0-55,1$ & 100,00 & $88,3-100,0$ \\
$>3,2$ & 13,33 & $2,0-40,5$ & 100,00 & $88,3-100,0$ \\
$>5,1$ & 0,00 & $0,0-22,0$ & 100,00 & $88,3-100,0$ \\
\hline
\end{tabular}

Keterangan: $\mathrm{IK}=$ interval kepercayaan

belakang sosioekonomi yang tidak jauh berbeda. Kedua, penelitian ini tidak mempergunakan skor PRISM 2 sebagai pembanding memprediksi kematian pada penderita pneumonia. Hal ini disebabkan karena sistem skoring ini memerlukan biaya mahal untuk pemeriksaan fungsi seluruh organ dan software khusus serta memerlukan pelatihan khusus dan panduan ketat untuk mencegah variasi interobserver yang lebar. ${ }^{3,4}$ Ketiga, penelitian ini hanya menganalisis kadar D-dimer plasma sebagai variabel koagulasi. Walaupun penelitian oleh Michelin dkk..$^{20}$ telah menunjukkan D-dimer plasma sebagai variabel koagulasi dan fibrinolitik yang lebih bermakna dibandingkan dengan prothrombin time (PT) dan activated partial thromboplastin time (aPTT) untuk menilai beratnya komplikasi pneumonia, tetapi analisis terhadap PT, aPTT, fibrinogen serta tromboelastografi (TEG) terhadap keluaran penderita pneumonia mungkin memberikan hasil yang berbeda.

Simpulan, kadar D-dimer plasma $>0,4 \mathrm{mg} / \mathrm{L}$ dapat digunakan sebagai prediktor kematian penderita pneumonia usia 2 sampai 59 bulan.

\section{Daftar Pustaka}

1. WHO. Pneumonia: the forgotten killer of children. Geneva: WHO; 2006.

2. Departamen Kesehatan RI. Riset kesehatan dasar 2007. Jakarta: Dep Kes RI; 2008.

3. Van Keulen JG, Polderman KH, Gemke RJBJ. Reliability of PRISM and PIM scores in paediatric intensive care. Arch Dis Child. 2005;90:211-4.

4. Qureshi AU,AliAS, Ahmad TM. Comparison of three prognostic scores (PRISM, PELOD and PIM 2) at pediatric intensive care unit under pakistani circumstances. J Ayub Med Coll Abbottabad. 2007;19(2):49-53.

5. Gunther A, Mosavi P, Heinemann S, Ruppert
C, Muth H, Markart P, dkk. Alveolar fibrin formation caused by enhanced procoagulant and depressed fibrinolytic capacities in severe pneumonia. Comparison with the acute respiratory distress syndrome. Am J Respir Crit Care Med. 2000;161:454-62.

6. Querol-Ribelles JM, Tenias JM, Grau E, Querol-Borras JM, Climent JL, Gomez E, dkk. Plasma d-Dimer level correlate with outcomes in patients with community acquired pneumonia. Chest. 2004;126:108792.

7. Levi M, Keller TT, Gorp E, Cate H. Infection and inflammation and the coagulation sistem. Cardiovasc Res. 2003;60:26-39.

8. Van der Poll T. Tissue factor as an initiator of coagulation and inflammation in the lung. Crit Care. 2008;12(Suppl 6):S3.

9. Shorr AF, Thomas SJ, Alkins SA, Fitzpatrick TM, Ling GS. D-dimer correlates with proinflammatory cytokine levels and outcomes in critically ill patients. Chest. 2002;121:1262-8.

10. Franchini M, Lippi G, Manzato F. Recent acquisitions in the pathophysiology, diagnosis and treatment of disseminated intravascular coagulation. Thrombosis J. 2006;4:4.

11. Milbrandt EB, Reade MC, Lee MJ, Shook SL, Angus DC, Kong L, dkk. Prevalence and significance of coagulation abnormalities in community-acquired pneumonia. Mol Med. 2009; 15(11-12):438-45.

12. Bjork O, Braback L. A retrospective population based trend analysis on hospital admission for lower respiratory illness among swedish children from 1987 to 2000 . BMC Public Health. 2003;3:22.

13. Azad KMAK. Risk factors for acute respiratory infections (ARI) among children under five years in Bangladesh. J Sci Res. 2009;1(1):72-81. 
14. Coles CL, Fraser D, Givon-Lavi N, Greenberg D, Gorodischer R, Bar-Ziv J, dkk. Nutritional status and diarrheal illness as independent risk factors for alveolar pneumonia. Am J Epidemiol. 2005;162:999-1007.

15. Sunyataningkamto, Iskandar Z, Alan RT, Budiman I, Surjono A, Wibowo T, dkk. The role of indoor air pollution and other factors in the incidence of pneumonia in under-five children. Paediatr Indones. 2004;44:25-9.

16. WHO Indonesia. Pelayanan kesehatan anak di rumah sakit. Pedoman bagi rumah sakit rujukan tingkat pertama di kabupaten/kota. Jakarta: WHO Indonesia; 2009.

17. Shilon Y, Shitrit AB, Rudensky B, Yinnon AM, Margalit M, Sulkes J, dkk. A rapid quantitative D-dimer assay at admission correlates with the severity of community acquired pneumonia. Blood Coagul Fibrinolysis. 2003;14(8):745-8.

18. Adam SS, Key NS, Greenberg CS. D-dimer antigen: current concepts and future prospects. Blood. 2009;113(13):2878-87.

19. Levi $M$. The diagnosis of disseminated intravascular coagulation made easy. Neth J Med. 2007;65(10):366-7.

20. Michelin E, Snijders D, Conte S, Dalla Via P, Tagliaferro T, Da Dalt L, dkk. Procoagulant activity in children with community acquired pneumonia, pleural effusion and empyema. Pediatr Pulmonol. 2008;43:472-5. 